\title{
DILA Learning Model based on Contextual Teaching and Learning in Applied Physics Course at Mining Engineering
}

\author{
Fadhilah \\ Mining EngineeringDepartment \\ Universitas Negeri Padang \\ Padang, Indonesia \\ fadhilah@ft.unp.ac.id
}

\author{
Z. Mawardi Efendi, Ridwan \\ Technology and Vocational Education \\ Universitas Negeri Padang \\ Padang, Indonesia
}

\begin{abstract}
Applied physics as a science is used to understand other sciences and as a basis for technological development. Learning Physics not only learns facts, concepts, principles, and laws, but also learns how to learn physics to gain information, scientific work steps, and the application of science and technology. This study found a learning model that can link learning materials with contextual application. Contextual Teaching and Learning (CTL) is a contextual learning model that has not had its own syntax, only has seven principles in its implementation. It is important to do research that develops the CTL model into a learning model that has syntax so that it can be used at the same time in its learning stages. This study resulted in the DILA learning model developed from seven CTL principles with the IDI development procedure (Instructional Development Institute). DILA learning model has syntax Display, Inquiry, Learning Community and Authentic Assessment. This model was validated by the experts and tested experimentally on the D3 Mining Engineering students FT UNP with 19 students in the control class and 31 students in the experimental class. Model validation shows 0.81 practicality 0,84 and effectiveness can improve student learning result of experimental class significantly on $95 \%$ confidence level and effect size 0,82 .
\end{abstract}

Keywords-applied physics, mining engineering, DILA learning model

\section{INTRODUCTION}

In accordance with the characteristics of learning process in the contextual and student-centered, learning must make students active and able to construct their own knowledge. Learning is not only focused on providing knowledge of theoretical skills only, but how to have the learning experience owned by the student is always associated with actual problems that occur in the environment. Contextual Teaching and Learning (CTL) is a system that links any material or learning topic with real life. Various ways can be done such as giving illustrations and examples, learning resources, media and so on, which are either directly or indirectly related to real life experiences. CTL is a learning system that matches the performance of the brain, to construct patterns that embody meaning, by linking the academic content with the context of everyday life of the learners. This is important so that the information received is not only stored in short-term memory, which is easily forgotten, but can be stored in long-term memory so that it can be appreciated and applied in the job task.

As a model of learning, CTL does not yet have all the features required in a teaching model. According to Eiggen and Kauchak [1] the teaching model is a specific approach in teaching that has three characteristics: goals, phases (a series of steps aimed at helping students achieve specific learning objectives) and foundation (supporting theories and studies). In the CTL book written by Elaine B. Johnson there is no special syntax of learning in implementing the CTL model. CTL has eight interrelated components [2]. But many researchers are making learning strategies in implementing this CTL.

Some of the learning strategies that are based on CTL are RANGKA (Rumuskan Amati Nyatakan Gabungkan Komunikasikan dan Amalkan) used in Biology learning [3] and REACT (Relating Experiencing Applying Communicating and Implementing) in Mathematics learning [4]. The objectives of Applied Physics course are: Students are able to apply learning material in the field of mining and have critical and contextual attitude as an expert. Applied Physics Learning requires a learning step that demonstrates the application of learning materials in the mining industry. The mining environment also requires a solid teamwork to complete the work. Students should be familiarized by working together in groups so that their ethics and attitude are already formed to work in groups. Applied Physics Learning requires a learning model that is able to bring students into the mining environment to demonstrate the application of learning materials.

The first step in Applied Physics learning using the DILA learning model is to display the application of materials in the mining industry through video (Display). According to the study of Zulkarnain et al [5] which states that learning using contextual video can increase student learning outcomes. The student's initial perception of the material will be formed at this stage. Then the lecturer asks questions related to the material in accordance with the video show so that students associate the knowledge they already have with the material. At this stage students find the concept of learning materials either from the answers to questions or from experiments that they do (Inquiry). Inquiry is an effective way to learning applied physics [6][7][8][9]. Furthermore, students are grouped in solving problems or 
assigned tasks (learning community). Students are more open to learning by discussing with their friends [10]. Assessment is done based on authenthic assessment, students are judged not only from the test results but also from the results of the tasks, attitudes and skills they produce. These four steps; Display, Inquiry, Learning Community, and Authenthic assessment are syntax of the learning model which is named DILA Learning Model (Display, Inquiry, Learning community, and Authenthic Assessment).

As an illustration in the implementation of this syntax we can observe in the learning material quantities and units. The lecturer shows a video of an excavator filling a dump truck. After the video aired, the lecturer will ask what the basic concept should be known in the charging process from the side of the bucket excavator and dump truck. From the video show the student will understand that the bucket excavator has its own capacity as well as the dump truck. They will count how many times the dump truck is loaded by the excavator so that the dump truck is fully loaded. Here they will recognize mass, density, and volume. It is expected that by implementing this learning syntax the students understand the learning material in contextual.

This DILA Model learning synergy is also developed from seven CTL principles. The principle of constructivism and modeling is represented by the Display step, the principle of inquiry and questioning summarized in the step of inquiry, while the principles of reflection and learning community seen from the steps of community learning and authentic assessment are used entirely in the final stages of this DILA model. DILA model is constituted by three basic theories are contextual, student centered learning and collaboration. These three theories are in accordance with the objectives of Applied Physics learning and learning achievement of D3 program according to KKNI.

Contextual is a learning concept whereby the lecturer associates the material he or she taught to the real-world situations of the student and encourages students to make the connection between their knowledge and application in their life. Student centered learning is the achievement of graduate learning through learning process that prioritizes creativity, capacity, personality, and student needs and develops independence in finding and finding knowledge. While the collaboration is the achievement of graduate learning achieved through the process of learning together that involves interaction between individual learners to produce capitalization of attitudes, knowledge, and skills. The three basic theories of DILA model are in accordance with Permenristekdikti no. 44 years 2015.

In relation to the implementation of curriculum according to KKNI conducted no later than 2017, the learning of Applied Physics course should be able to provide meaningful learning in accordance with its application in the mining industry. Implementation of previous learning centered learning teacher should be changed to student centered learning so that learning model is needed that can make it happen. The DILA learning model looks very accommodating to the demands of the curriculum according to KKNI so the research to produce a valid, effective and effective DILA Model is important.

\section{METHOD}

\section{A. Research Procedure}

This research is conducted in D3 Mining Engineering students of FT UNP who take Applied Physics semester of July-December 2017. This research is a development research using IDI (Instructional Development Institute) procedure with stages: define, develop and evaluate [17]. The effectiveness of the resulting model was tested by performing quasi experiments with pretest-posttest control group design. The development procedures implemented are:

\section{1) Define}

There are three stages: identification problem, analyze setting, and organizational management. These three stages are identified from the initial research questionnaire that contains the needs analysis. The analysis was conducted on students, lecturers, learning materials and tasks [18].

\section{2) Develop}

The development stage begins with studying the general objectives of Applied Physics courses or now known as learning outcomes. Then make the design of the learning model in accordance with the structure of the learning model according to Joyce and Weill. The designs that have been completed with validity testing instruments are discussed in the FGDs attended by Education Technology experts. Expert of Vocational Expert Learning Technology, Physics Expert and from user (industry).

\section{3) Evaluate}

Validation of research instrument conducted by 2 experts. Research instrument in the form of questionnaire in Likert scale about validation of learning model, learning model practicality and pretest-posttest to measure the effectiveness of learning model. After the instrument was validated, a small group trial was conducted with 7 students in $4 \mathrm{x}$ faceto-face meetings. The result of the experiment analyzed and then revised the learning model. An expanded trial was conducted on 50 students consisting of control classes and experimental classes.

\section{B. Technique of Data Analysis}

1) Validity and Reliability of Research Instruments

Before the instrument of research is given to the subject of research, it was first tested regarding its validity by the experts. There are two experts who validate this research instrument. The data processing of the instrument validation results employ Aiken's (V) equation [19]. Instrument reliability is obtained from alpha cronbach value using SPSS version 16.

\section{2) Validity and Practicality of Development Model}

The results of this questionnaire were processed statistically by tabulation technique by determining total score, score average, ideal score and percentage of respondent's level of achievement (TCR) as in (1).

Level of Achievement $=$ average score/ideal score $\mathrm{x} 100 \%(1)$ 
TABLE I. CRITERIA OF VALIDITY [20]

\begin{tabular}{|l|l|l|}
\hline No. & \multicolumn{1}{|c|}{ Score } & \multicolumn{1}{c|}{ Category } \\
\hline 1. & $85,01 \%-100 \%$ & $\begin{array}{l}\text { Very valid, or can be used without } \\
\text { revision }\end{array}$ \\
\hline 2. & $70,01 \%-85 \%$ & $\begin{array}{l}\text { Quite valid, or usable but needs a } \\
\text { small revision }\end{array}$ \\
\hline 3. & $50,01 \%-70,00 \%$ & $\begin{array}{l}\text { Less valid, recommended not used } \\
\text { because it needs major revision }\end{array}$ \\
\hline 4. & $01,00 \%-50,00 \%$ & Invalid, or may not be used \\
\hline
\end{tabular}

TABLE II. CRITERIA OF PRACTICALITY [21]

\begin{tabular}{|l|c|}
\hline \multicolumn{1}{|c|}{ Score (\%) } & Category \\
\hline $80<\mathrm{TCR} \leq 100$ & Very Practical \\
\hline $60<\mathrm{TCR} \leq 80$ & Practical \\
\hline $40<\mathrm{TCR} \leq 60$ & Practical Enough \\
\hline $20<\mathrm{TCR} \leq 40$ & Less Practical \\
\hline $\mathrm{TCR}<20$ & Not Practical \\
\hline
\end{tabular}

3) Effectiveness of Development Model

The test is done to see the difference of students' ability from the pre test and post test in the control class and the experimental class. Level of trust used $95 \%$ and also determined effect size from giving treatment in the form of learning by using DILA learning model in experiment class.

\section{RESULT AND DISCUSSION}

The pre-deployed research instrument is validated by an expert. There are two experts who validate the education technology experts and experts in Applied Physics. The evaluated aspects were contents feasibility, construction feasibility, and language accuracy.

TABLE III. INSTRUMENT VALIDATION RESUlTS BY TwO EXPERTS

\begin{tabular}{|l|l|l|l|l|}
\hline No. & \multicolumn{1}{|c|}{ Instruments } & Validity & Reliability & Category \\
\hline 1 & Model Validity & 0,9 & 0,952 & Good \\
\hline 2 & Model Practicality & 0,875 & 0,857 & Good \\
\hline 3 & $\begin{array}{l}\text { Item Pre test and } \\
\text { Posttest }\end{array}$ & 0,88 & 0,956 & Good \\
\hline
\end{tabular}

After the research instrument is feasible to be used visible from the value of validity and high reliability, the instrument is distributed to the lecturers of the subjects of Applied Physics and Educational Technology experts to measure the validity of the model. The instrument of practicality is distributed to students in the experimental class.

\section{A. Validity of DILA Learning Model}

Model validity about rational model, model supporting theory, development objectives, syntax, social system, reaction principles, supporting system and impact application of DILA learning model. This validity instrument is given to the lecturers of Physics Applied subjects, educational technology experts and vocational education experts.

TABLE IV. VALIDATION Results of DILA LEARNING Model

\begin{tabular}{|c|c|c|c|}
\hline No. & Experts & Score & Category \\
\hline 1. & YN & 0,875 & Valid \\
\hline 2. & US & 0,79 & Valid \\
\hline 3. & AI & 0,875 & Valid \\
\hline
\end{tabular}

The validation results of the three experts show a valid DILA learning model to be used.

\section{B. Practicality of DILA Learning Model}

The results of model practice with questionnaires that have been validated by experts to 31 students in the experimental class showed the number of 0.84 where the DILA learning model is very practical to be implemented in Applied Physics course.

\section{Effectiveness of DILA Learning Model}

The effectiveness of the DILA learning model was observed from quasi experimental results with pretestposttest control group design. 50 students of D3 Mining Engineering that take the Applied Physics semester from July to December 2017 are used as research subjects divided into control class and experiment class. pretest is given to both classes to see students' ability in both classes. Table 5 . Results of pre test and post test of DILA learning model implementation.

\section{TABle V. Results of PreTest-Postest}

\begin{tabular}{|l|l|l|l|l|l|l|}
\hline & Class & $\begin{array}{c}\text { Total } \\
\text { Score }\end{array}$ & Mean & SD & SD $^{2}$ & SS \\
\hline \multirow{2}{*}{$\begin{array}{l}\text { Pre } \\
\text { Test }\end{array}$} & Control & 524 & 29,11 & 9,486 & 85,43 & 1537,68 \\
\cline { 2 - 7 } & Experiment & 924 & 29,81 & 11,02 & 121,43 & 3642,84 \\
\hline \multirow{2}{*}{$\begin{array}{l}\text { Post } \\
\text { test }\end{array}$} & Control & 1066 & 56,11 & 11,2 & 125,44 & 2259,8 \\
\cline { 2 - 7 } & Experiment & 2066 & 66,7 & 13,98 & 195,44 & 5867,1 \\
\hline
\end{tabular}

The result of calculation of sample normality in control class by using Kolmogorov-Smirnov One-Sample Test of SPSS version 16 obtained by Asymp.Sig 0.217>0,05 means that control class is normally distributed. Result of calculation of sample normality in experiment class by using One-Sample Test Kolmogorov-Smirnov Test SPSS version 16 obtained Asymp.Sig 0.280>0,05 so that sample in this experiment class is normal distributed. The homogeneity test between the two samples is then done to see whether the two classes have the same variance. The result of homogeneity of variance of sample class obtained $\mathrm{F}=1.42$. $\mathrm{F}$ table with $\mathrm{dk}$ (31/19) at $\alpha=0.05$ is 2.014 (interpolated result). So that Fh $<$ Ftabel is obtained, the variant of the two classes is homogeneous. Results of data processing using SPSS version 16 also obtained $\mathrm{t}(48)=0.179$ and Sig. (2-tailed) $>0.05$. Based on the above statistical test results, it can be concluded that both classes deserve to be used as experimental class and control class because it has homogeneous variant, normal and have the same ability so that experiment can be done by giving learning using DILA learning model in experiment class and conventional learning in the control class.

After 16 meetings in both the experimental and control classes, another post test was given to see the effect of the treatment on learning outcomes. Normality test results in control class Asymp.Sig 0.935>0.05 so that samples in the control class are normally distributed. The result of normality test in experimental class Asymp.Sig 0,226>0,05 so that sample in experiment class is normally distributed. The homogeneity test between the two samples is then done to see whether the two classes have the same variance. The result of the homogeneity of the variance of the sample class obtained the value $\mathrm{Fh}$ ( $\mathrm{F}$ arithmetic) is 1.558. F table with $\mathrm{dk}$ $(31 / 19)$ at $\alpha=0.05$ is 2.014 (interpolated), so that $\mathrm{Fh}<$ Ftabel is obtained, then the variant of the two classes is homogeneous. If both classes are homogeneous, proceed 
with t test to see if the ability of the two classes is the same or different. Paired Sample Test with SPSS data processing $\mathrm{t}$ $(30)=12,144$ with Sig. (2-tailed) $<0.05$. This means that the treatment provided causes a great influence on the learning outcomes, where there is a significant increase in learning outcomes with prior treatment. The effect size obtained is $\mathrm{d}=$ 2.18 , where this value is bigger than 0.8 so according to Cohen giving very big influence to the increase of learning result.

Every step of the DILA syntax is very appropriate in Applied Physics learning. At the learning stage of Display, learning step is the lecturer explain syllabus, learning outcome and indicators of learning achievement. Then the lecturer presents a video about the application of learning materials in the mining industry. It is hoped that by looking at this video, students can relate the knowledge they have gained with the implementation shown. The results of [5] suggest that learning using contextual video is more effective than those who do not use video.

Inquiry learning stages involve students to think critically and creatively. [6], [7], and [8] conducted research by providing inquiry-based learning in the experimental class. The learning outcomes in the experimental class are higher than the control class. Stages of learning community are to familiarize students working in teams. Students will be more open with friends in solving problems [10]. [14],[16] stated that collaborative learning involves shared intellectual effort by students, or students and lecturers together in discussions, creation, and decision-making.

The learning stages of authentic assessment are oriented towards a continuous process and learning outcomes that reflect students' ability during the learning process. The results of [22] and [23] showed that authentic assessment can measure students' competence from the cognitive, affective, and psychomotor domains.

If we see the description of DILA model learning steps, they are close to the scientific approach in accordance with the wishes of the curriculum 2013. In addition to providing physics learning in the form of theory, lecturers must also teach how scientific discovery science [24].

\section{CONCLUSION}

This study produced a valid, practical and effective DILA-based CTL learning model. The DILA model developed is based on three main theories: Contextual, Student Centered Learning and Collaborative. The three main theoretical foundations are well suited to the objectives of Applied Physics learning. The study of Applied Physics course is different from that of Basic Physics and General Physics. Applied Physics courses should be able to provide the application of materials in accordance with the expertise of students who study them. The Applied Physics course for Mining Engineering should be able to provide examples of application in accordance with the mining industry. DILA learning models have a simple syntax of Display, Inquiry, Learning community and Authentic Assessment. DILA learning model can improve students' learning outcomes in Applied Physics course. The researcher recommends for physics teachers to apply this learning model. Further researches are required by different models.

\section{REFERENCES}

[1] Eiggen, Paul and Kauchak, Don. "Strategi dan Model Pembelajaran Mengajarkan konten dan keterampilan berpikir". Pent : Satrio Wahono. PT. Indeks Permata Puri Media.2012. Jakarta

[2] Johnson, Elaine B. "Contextual Teaching and Learning : Menjadikan kegiatan belajar-mengajar mengasyikkan dan bermakna.' Penerjemah, Ibnu Setiawan; Ida Sitompul, Cet -1. Kaifa.2014. Bandung

[3] Evi Suryawati, K. O., T.Subahan Mohd Meerah. "The effectiveness of RANGKA contextual teaching and learning on students' problem solving skills and scientific attitude." Procedia Social and Behavioral Sciences 9.2010: 1717-1721

[4] Crawford, Michael L."Teaching Contextually, Research, Rationale, and Techniques for Improving Student Motivation and Achievement in Mathematics and Science". CCI Publishing, Inc.2001. ISBN 157837-321-2

[5] Zulkarnain Md Amin, N. K. M. K., Wan Mohd Rashid bin Wan Ahmad and Maizam Alias. "Impact of Contextual Video in Learning Engineering Statistics in The Universiti Tun Hussein Onn Malaysia (UTHM)." International Journal of Arts \& Sciences, CD-ROM.2011. ISSN: 1944-6934 :: 4(11):195-202 (2011) Copyright c 2011 by InternationalJournal.org: 195-202.

[6] Abdi, A. "The Effect of Inquiry-based Learning Method on Students' Academic Achievement in Science Course. Universal Journal of Educational Research ,2014. 37-41

[7] Jurubahasa Sinuraya. "Inquiry-Oriented Learning Material to Increased General Physics Competence Achievement. Journal of Education and Practice". ISSN 2222-1735 (Paper) ISSN 2222-288X (Online). Vol.7, No.28, 2016

[8] Almuntasheri, S., Gillies, R. M., \& Wright, T. "The Effectiveness of a Guided Inquiry-based, Teachers' Professional Development Programme on Saudi Students' Understanding of Density”. Science Education International, 2016.16-39.

[9] Korganci, Nuri et al." The Importance of Inquiry-Based Learning on Electric Circuit Models for Conceptual Understanding" Procedia Social and Behavioral Sciences. 2015 p. 2463-2468

[10] Panitz, Theodore."Collaborative versus Cooperative Learning: A Comparison of the Two Concepts Which Will Help Us Understand the Underlying Nature of Interactive Learning". EDRS. ERIC Processing and Reference Facility. 1999. http://files.eric.ed.gov/ fulltext/ED448443.pdf di akses 6 Agustus 2017

[11] Bambang Warsita. (2008). Teknologi Pembelajaran, Landasan dan Aplikasinya. Rineka Cipta. Jakarta.

[12] O'Neill, Geraldine and Tim Mc Mahon."Student-centred learning: What does it mean for students and lecturers?".2005. http:/www.aishe.org/readings/2005-1

[13] Sutrisno dan Suyadi."Desain Kurikulum Perguruan Tinggi mengacu Kerangka Kualifikasi Nasional Indonesia”. PT. Remaja Rosdakarya 2015.Bandung

[14] Panitz, Theodore."Collaborative versus Cooperative Learning: A Comparison of the Two Concepts Which Will Help Us Understand the Underlying Nature of Interactive Learning". EDRS. ERIC Processing and Reference Facility. 1999. http://files.eric.ed.gov /fulltext/ED448443.pdf di akses 6 Agustus 2017

[15] Gregor, B. L. (1992) https://www.researchgate.net/publication/ 242282475. Dipetik Agustus 6, 2017

[16] Zhang, X., Anderson, R. C., Morris, J., Miller, B., Nguyen - Janiel, K. T., Lin, T., Zhang, J., Jadallah, M., Scott, T., Sun, J., Latawjec, B., Ma, S., Grabow, K., \& Hsu, J. Y." Improving children's competence as decision makers: Contrasting effects of collaborative interaction and direct instruction". American Educational Research Journal,2016. 53, 194-223. doi: 10:3102/0002831215618663. http://files.eric.ed.gov /fulltext/ED571844.pdf di akses 6 Agustus 2017

[17] Laal, M. L.'Collaborative learning: what is it?". 2012.491 - 495. Procedia - Social and Behavioral Sciences, 491-495.

[18] Seels, Barbara dan Glasglow, Rita."Making Instructional Design Decisions". 2nd ed. 1998.

[19] http://ocw.metu.edu.tr/pluginfile.php/3298/course/section/1175/2012 1127191305441.pdf . diakses tanggal 15 Juli 2017

[20] Fadhilah." Needs analysis of instructional models in the course of applied pysics at the department fo Mining Engineering". ASEAN Comparative Education Research Network Conference, November 
30th - December 01st 2016. Proceeding Hal 364-369. ISBN: 978983-2267-95-9

[21] Aiken, L. R."Content Validity and Reliability of Single Items or Questionnaires. Educational and Psychological Measurement," .1980.955-959.

[22] Sa'adun Akbar."Instrumen Perangkat Pembelajaran". PT. Remaja Rosda Karya. 2013. Bandung

[23] Riduwan. "Belajar Mudah Penelitian untuk Guru -Karyawan dan Peneliti Pemula".Alfabeta. 2009.Bandung

[24] Indah Rakhmawati Afrida."Pengembangan Model Penialian Otentik untuk Mengukur Capaian Pembelajaran Mahasiswa”. Jurnal Biologi dan Pembelajaran Biologi,2016. 137-147.

[25] Kabil, Onur."Philosophy in physics education" Procedia - Social and Behavioral Sciences. 2015 p. $675-679$. 